\title{
Methodological approaches to the development of a digital model for analysis and evaluation of insolvency of joint- stock machine companies
}

\author{
Enfoques metodológicos para el desarrollo de un modelo digital para el análisis y la \\ evaluación del riesgo de insolvencia de empresas fabricantes de maquinarias
}

\author{
VLADIMIROVNA, Kalinina Tatiana ${ }^{1}$ \\ VASILIEVNA, Vasilchuk Elena ${ }^{2}$ \\ KASYMBEKOVNA, Kurmangaliyeva Aizhan ${ }^{3}$ \\ BAIZAKOVICH, Baizakov Sabit ${ }^{4}$ \\ VALENTINOVNA, Lysenko Yulia ${ }^{5}$ \\ VALENTINOVICH, Lysenko Maxim ${ }^{6}$ \\ VLADIMIROVICH Belokonov Yuri ${ }^{7}$
}

\begin{abstract}
In this article, the application of the policy for managing the risk of insolvency is relevant, methodological approaches to the development of a digital model for analyzing and assessing the risk of insolvency are considered, which is focused on the universal concept of liquidity management for a machine-building company, taking into account the following algorithm: the principle of effective management of the structure of working capital; the principle of efficient use of financial resources; the principle of restoring solvency; the principle of effective management of borrowed funds and the principle of effective use of labor resources.
\end{abstract}

Keywords: insolvency, risk, solvency analysis, financial activity, methods of assessing insolvency

\begin{abstract}
RESUMEN: En este artículo es relevante la aplicación de la política de gestión del riesgo de insolvencia, se consideran enfoques metodológicos para el desarrollo de un modelo digital de análisis y evaluación del riesgo de insolvencia, el cual se centra en el concepto universal de gestión de liquidez para un empresa de construcción de máquinas, teniendo en cuenta el siguiente algoritmo: el principio de gestión eficaz de la estructura del capital de trabajo; el principio de uso eficiente de los recursos financieros; el principio de restablecimiento de la solvencia; el principio de gestión eficaz de los fondos prestados y el principio de uso eficaz de los recursos laborales.

Palabras clave: insolvencia, riesgo, análisis de solvencia, actividad financiera, métodos de evaluación de la insolvencia
\end{abstract}

\footnotetext{
${ }^{1}$ General director Consult Retail s.r.o Prague-5, E-mail: tatiana-tatiana2014@inbox.ru

${ }^{2}$ Doctor of Economics, Deputy Director for Career and Employment, Kostanay Regional University named after A. Baitursynov, E-mail: elenavasilchuk@cspu.ru

${ }^{3}$ PhD in Economics, Institute of Distance Learning and Additional Education, Kostanay Regional University named after A. Baitursynov, E-mail: bektau@mail.ru

${ }^{4}$ Academician, National Academy of Sciences of Kazakhstan, E-mail: bektau@mail.ru

${ }^{5}$ Doctor of Economics, Professor of the Department of Economics, Finance and Management of the Financial University under the Government of the Russian Federation, Professor of the Department of Economics, Management and Law of the South Ural State Humanitarian Pedagogical University (CSPU), E-mail: Iysenkoyuv@cspu.ru

${ }^{6}$ Doctor of Economics, Professor of the Department of Economics and Management, Educational institution of higher education "South Ural Technological University", E-mail: dec_eib@mail.ru

${ }^{7}$ Senior Lecturer, Chelyabinsk State University, E-mail: superbest@inbox.ru
} 


\section{Introduction}

\subsection{Research rationale and literature review}

In modern economic conditions, the risk of insolvency is quite high and financial discipline suffers. Therefore, great importance is attached to the analysis of solvency, assessment of liquidity, assessment of the risks of insolvency and the likelihood of bankruptcy.

In this regard, the development of a digital analysis model and the assessment of the risk of insolvency is increasing.

The relevance of our research is to develop a digital model for the analysis and assessment of the risk of insolvency, which will, in a complex, universally analyze the financial and economic state. According to the authors Smirnov y Trofimov (2015), the company's solvency is extremely unstable. For example, upon maturity of accounts payable and lack of funds in the bank, due to late receipt of payments for goods previously supplied to customers, the company will become insolvent due to financial indiscipline of its debtors. Even in spite of the fact that by the composition of assets the company has a liquid balance and has the ability to attract borrowed funds.

According to the author Kudryavtsev (2015), the definition of solvency as the ability of a debtor to fulfill obligations on time corresponds to reality, but none of the researchers presented above believed that not only the ability to fulfill obligations, but also desires, was needed. Thus, insolvency is the inability and / or unwillingness of the debtor to fulfill obligations when the time comes. In practice, an assessment of the risk of insolvency should be done before entering into a transaction. Insolvency risk assessment should be done using the same methods used by lenders. Thus, when issuing a loan, the lender assesses the risk of the borrower's insolvency. According to Kudryavtsev (2015), the reasons for the risk of insolvency:

a) lack of desire to fulfill current obligations;

b) the lack of cash or liquid assets with which these obligations can be repaid. It is most interesting to study the experience of regions that successfully implement projects in assessing the risks of insolvency.

\subsection{General characteristics of research facilities}

The study was carried out on the basis of materials from the Ural Federal District (hereinafter Ural Federal District).

The most important industry and the pride of the industry of the Urals District is mechanical engineering. The Ural Federal District produces almost $10 \%$ of all machine-building products in the country. The enterprises of this industry produce up to $60.8 \%$ of freight railway cars in the Russian Federation, $21 \%$ of bridge structures. Equipment with the brand of the Ural companies, which is unique and of high quality, is installed at the leading petrochemical, metallurgical and machine-building plants in Russia. Ural machine-building enterprises are the largest exporters of their products to world markets. Developed enterprises of the machine-building industry are located in the south of the Tyumen region, in the Sverdlovsk, Chelyabinsk and Kurgan regions. Among the leading enterprises of the Tyumen region for the production of trailers, batteries and woodworking machines: JSC Tyumen Motor Engineers, JSC Welding Electrode Plant, JSC Neftemash, JSC Tyumen Battery Plant, JSC Tyumen Shipbuilding Plant, etc. 
The study was carried out using materials from Russian enterprises that manufacture and sell more than 50 types of processing and mining equipment. Our research was carried out at joint-stock companies in the region.

The task of the activity, which includes the release of high-quality products aimed at meeting the needs of customers, who are not only representatives of the Russian Federation, but also the neighboring countries: enterprises of Kazakhstan, Belarus, Estonia, as well as far abroad: China, Iran.

\section{Materials and methods}

\subsection{Global trends in digital models of analysis and assessment of insolvency risks}

The study showed that there are various methods of assessing insolvency, which are used to calculate the likelihood of the risk of insolvency of enterprises, according to the developed criteria. In practice, several types of techniques are used today with their own distinctive features. The historical aspect of its origin is presented in the table 1.

Table 1

Evolution of methods of assessing solvency

\begin{tabular}{|l|l|}
\hline $\begin{array}{l}\text { Initial Application / } \\
\text { Year of development }\end{array}$ & $\begin{array}{l}\text { Name of the developed methodology for assessing } \\
\text { solvency }\end{array}$ \\
\hline \multicolumn{1}{|c|}{1} & \multicolumn{1}{|c|}{2} \\
\hline 1909 r. until now & Rating models Moody's \\
\hline 1916 г. until now & Rating models S\&P \\
\hline 1924 г. until now & Rating models Fitch \\
\hline 1868 & Z- Altman's model \\
\hline 1977 & Model Zeta \\
\hline 1999 & Dontsova and Nikiforova's technique \\
\hline 2000 & Moody's KMV RiskCalc v1.0 \\
\hline 2010 & Moody's KMV RiskCalc v3.1 Russia \\
\hline 2011 & Sinelnikova's model \\
\hline 2011 & Interfax Business Due Diligence Model \\
\hline 2013 & Financial risk assessment model for Interfax \\
\hline
\end{tabular}

One of the first models developed by Edward Altman, professor of finance at New York University, the "Z-model", as the author called it, emerged in 1868 and has become one of the most practically applied and successful for assessing the solvency of an enterprise. The "Z-model" allows you to estimate the probability of a company's default based on the calculated financial indicators. According to the authors Dontsova, Nikiforova (2015), Ilyina, Ukolova (2017), Volosevich (2015), Kovalenko (2016), and other scientists began to develop new models based on the analysis of indicators, the information base for the calculation of which was accounting data.

\subsection{A digital model for the analysis and assessment of the risk of insolvency, focused on a concept that includes five principles}

Let us evaluate the capabilities of the digital model for analyzing and assessing the risk of insolvency in relation to manufacturing companies, present the rationale for the goals of each direction in the proposed digital model, the applied coefficients table 2 . 
Table 2

Digital model of analysis and assessment of the risk of insolvency of engineering companies

\begin{tabular}{|c|c|c|}
\hline $\begin{array}{l}\text { Direction of analysis } \\
\text { and assessment of the } \\
\text { risk of insolvency }\end{array}$ & Purpose of analysis & Composition of coefficients \\
\hline 1 & 2 & 3 \\
\hline $\begin{array}{l}\text { Assessment of balance } \\
\text { sheet liquidity and } \\
\text { calculation of liquidity } \\
\text { ratios }\end{array}$ & $\begin{array}{l}\text { Group assets according to the } \\
\text { rate of conversion into cash } \\
\text { (and liabilities according to the } \\
\text { urgency of repayment of } \\
\text { obligations) to characterize the } \\
\text { provision of the most liquid } \\
\text { assets, determine the possibility } \\
\text { of repayment of the most } \\
\text { urgent obligations }\end{array}$ & $\begin{array}{l}\text { 1.1. Grouping of assets by degree of liquidity: } \\
\text { A1 - absolutely liquid assets; } \\
\text { A2 - quick realizable assets; } \\
\text { A3 - slow-moving assets; } \\
\text { A4 - hard-to-sell assets. } \\
\text { 1.2. Grouping of liabilities according to the maturity of } \\
\text { liabilities: } \\
\text { P1 - most urgent obligations; } \\
\text { P2 - short-term liabilities; } \\
\text { P3 - long-term liabilities; } \\
\text { P4 - permanent liabilities. } \\
\text { 1.3. Liquidity ratios: } \\
\text { absolute liquidity; } \\
\text { intermediate (urgent) liquidity; } \\
\text { current liquidity }\end{array}$ \\
\hline $\begin{array}{l}\text { Assessment of loss } \\
\text { (restoration) of } \\
\text { solvency }\end{array}$ & $\begin{array}{l}\text { Determine the trend of } \\
\text { decreasing (increasing) current } \\
\text { liquidity }\end{array}$ & $\begin{array}{l}\text { 2.1. Loss of solvency ratio; } \\
\text { 2.2. Solvency recovery ratio; } \\
\text { 2.3. Factor analysis of current liquidity }\end{array}$ \\
\hline $\begin{array}{l}\text { Assessment of the } \\
\text { turnover of current } \\
\text { assets }\end{array}$ & $\begin{array}{l}\text { Determine the efficiency of } \\
\text { resource use by calculating the } \\
\text { duration of circulation of } \\
\text { current assets }\end{array}$ & $\begin{array}{l}\text { 3.1. The turnover ratio of current assets; } \\
\text { 3.2. Cash turnover ratio; } \\
\text { 3.3. Accounts receivable turnover ratio; } \\
\text { 3.4. Accounts payable turnover ratio; } \\
\text { 3.5. Inventory turnover ratio }\end{array}$ \\
\hline $\begin{array}{l}\text { Cash flow liquidity } \\
\text { assessment }\end{array}$ & $\begin{array}{l}\text { Determine the sufficiency of } \\
\text { the cash flow for all settlements } \\
\text { and payments }\end{array}$ & $\begin{array}{l}\text { Liquidity ratios: } \\
\text { 4.1. Cash flow from current operations; } \\
\text { 4.2. Cash flow from investment transactions; } \\
\text { 4.3. Cash flow from financial transactions; } \\
\text { 4.4. Cumulative cash flow; } \\
\text { 4.5. Cumulative cash flow taking into account cash balance } \\
\text { at the beginning of the period }\end{array}$ \\
\hline $\begin{array}{l}\text { Cash flow efficiency } \\
\text { assessment }\end{array}$ & $\begin{array}{l}\text { Determine the possibility of } \\
\text { forming a free stock of funds } \\
\text { for a certain date after all } \\
\text { settlements and payments have } \\
\text { been made }\end{array}$ & $\begin{array}{l}\text { Efficiency ratios: } \\
\text { 5.1 Cash flow from current operations; } \\
\text { 5.2. Cash flow from investment transactions; } \\
\text { 5.3. Cash flow from financial transactions; } \\
\text { 5.4. Total cash flow }\end{array}$ \\
\hline $\begin{array}{l}\text { SWOT analysis in terms } \\
\text { of the risk of insolvency }\end{array}$ & $\begin{array}{l}\text { Determine the company's } \\
\text { ability to repay existing } \\
\text { obligations, identify threats, } \\
\text { risks of insolvency and outline } \\
\text { ways to reduce them }\end{array}$ & $\begin{array}{l}\text { 6.1. Strengths based on the analysis of solvency; } \\
\text { 6.2. Weaknesses; } \\
\text { 6.3. The company's capabilities in terms of timely } \\
\text { repayment of obligations; } \\
\text { 6.4. Insolvency threats }\end{array}$ \\
\hline
\end{tabular}

According to the authors Kurmaleeva y Grudina (2017); Lyagoshina (2017); Kovalenko y Kurilova (2016); Konstantinov (2017), the study showed that there are various methods of assessing insolvency, which are used 
to calculate the probability of the risk of insolvency according to the developed criteria. In practice, several types of techniques are used today, which have their own distinctive features. One of the first models developed by Edward Altman, professor of finance at New York University, the "Z-Model", as its author called it, appeared in 1868 and has truly become one of the most practical and successful approaches to company valuation. " solvency. The "Z-model" allows you to estimate the probability of a company's default based on the calculated financial indicators. On its basis, other scientists began to develop new models based on the analysis of indicators, the information basis for the calculation of which was represented by accounting data. Altman's model was developed using multiple linear discriminant analysis to select significant variables. Its construction consists in the process of sequential inclusion and exclusion of variables in the model in order to improve its predictive ability. Initially, the model included 22 variables, 22 different financial factors. According to the authors Kovalenko (2016); Gradova (2014); Kudryavtseva (2015), research showed that initially the model included 22 variables, 22 different financial factors. The choice of financial factors for the model was made on the basis of a discriminant analysis of 33 "good" companies and 33 "bad" companies. The variables with the least statistical significance were excluded from the model, after which the analysis of the significance of the variables was repeated.

As a result, the digital model began to include only five significant variables presented in table 3 .

Table 3

Assessment of factors used

in Altman's calculations

\begin{tabular}{|l|c|c|c|}
\hline Factor variable $\left(x_{n}\right)$ & $\begin{array}{c}\text { Average value for } \\
\text { the group of } \\
\text { insolvent } \\
\text { companies, } \%\end{array}$ & $\begin{array}{c}\text { Average value for } \\
\text { the group of } \\
\text { sustainable } \\
\text { companies, } \%\end{array}$ & F-statistics \\
\hline Own working capital / Total asset value & $-6,1$ & 41,4 & 32,60 \\
\hline Retained earnings / Total asset value & $-62,6$ & 35,5 & 58,86 \\
\hline Profit before tax / Total asset value & $-31,9$ & 15,4 & 26,56 \\
\hline Market value of capital / Carrying amount of liabilities & 40,1 & 247,7 & 33,26 \\
\hline Sales revenue / Total asset value & 150 & 190 & 2,84 \\
\hline
\end{tabular}

Elimination of the fifth variable has already led to a decrease in the predictive power of the model. Based on this fact, it was concluded that the discriminant five-factor function has the greatest predictive power. Let's present a general view of the model:

$$
Z=1,2 x_{1}+1,4 x_{2}+3,3 x_{3}+0,6 x_{4}+0,999 x_{5},
$$

dónde $Z$ - solvency index;

$$
x_{n} \text { - value } n \text { - factor. }
$$

According to the results of the analysis, it was revealed that the critical values of the index solvency (Z) set at 1.81 and 2.99. This means that those joint-stock machine-building companies, whose index value was determined at the level of less than 1.81, have a high probability of bankruptcy or default in the near future, such companies belong to the group of unconditionally insolvent. For those companies for which the value of the solvency index (Z) was determined at the level of more than 2.99, the probability of bankruptcy or default is low, such companies belong to the group of financially stable. If the solvency index takes a value between 1.81 and 2.99 , it is difficult to predict the probability of a default occurring. 
The digital model approach is to classify companies into two groups: companies that are unconditionally insolvent and companies that are financially stable.

The test results of the companies led to the conclusion that Altman's "Z-model" provides a more accurate forecast of the probability of a default occurring in the interval of one to two years. But it can only be applied to joint-stock machine-building companies that make up a complete set of financial statements (small enterprises submit a simplified version of the balance sheet and the statement of financial results, and do not make appendices to these reporting forms, and therefore, there is difficulty in accessing data for analysis ). Therefore, it is advisable to supplement the assessment of solvency with an analysis of cash flows, which will provide a real picture of the amounts of funds received and spent, identify the risks of insufficient funds by a certain date and will allow developing a schedule of receipts and payments in order to manage cash flows.

\section{Results}

\subsection{Possibilities and experience of applying the model of analysis and assessment of the risk of insolvency}

Figure 1 shows an algorithm for the content of the concept of liquidity management of an engineering company. The concept of liquidity management for machine-building companies should provide not only for the dynamic growth of its absolutely liquid assets, an increase in the rate of conversion of elements of current assets into cash, but also for the timely repayment of obligations and a decrease in the share of borrowed funds in the overall structure of the balance sheet.

The concept should contain a description of the funds that will be used to implement the liquidity management process for engineering companies. For this, it seems possible to use three types of means: organizational, pedagogical and economic.

The developed concept of liquidity management for machine-building companies. To do this, imagine:

a) a system of principles for managing liquidity;

b) we will formulate methodological techniques of financial management, which are the basis for the developed model of analysis and assessment of the risk of insolvency, key indicators, an algorithm for applying this model;

c) define the criteria and indicators that characterize the risks of reducing solvency.

Let us present the goals of creating the Concept of liquidity management for machine building companies:

a) economic goals - aimed at increasing the turnover of funds, accounts receivable, stocks, accounts payable;

b) financial - aimed at reducing the debt burden;

c) organizational - aimed at improving financial management;

d) social - aimed at improving personnel policy with high labor productivity and timeliness of production. 
Figure 1

The concept of liquidity management

of an engineering company

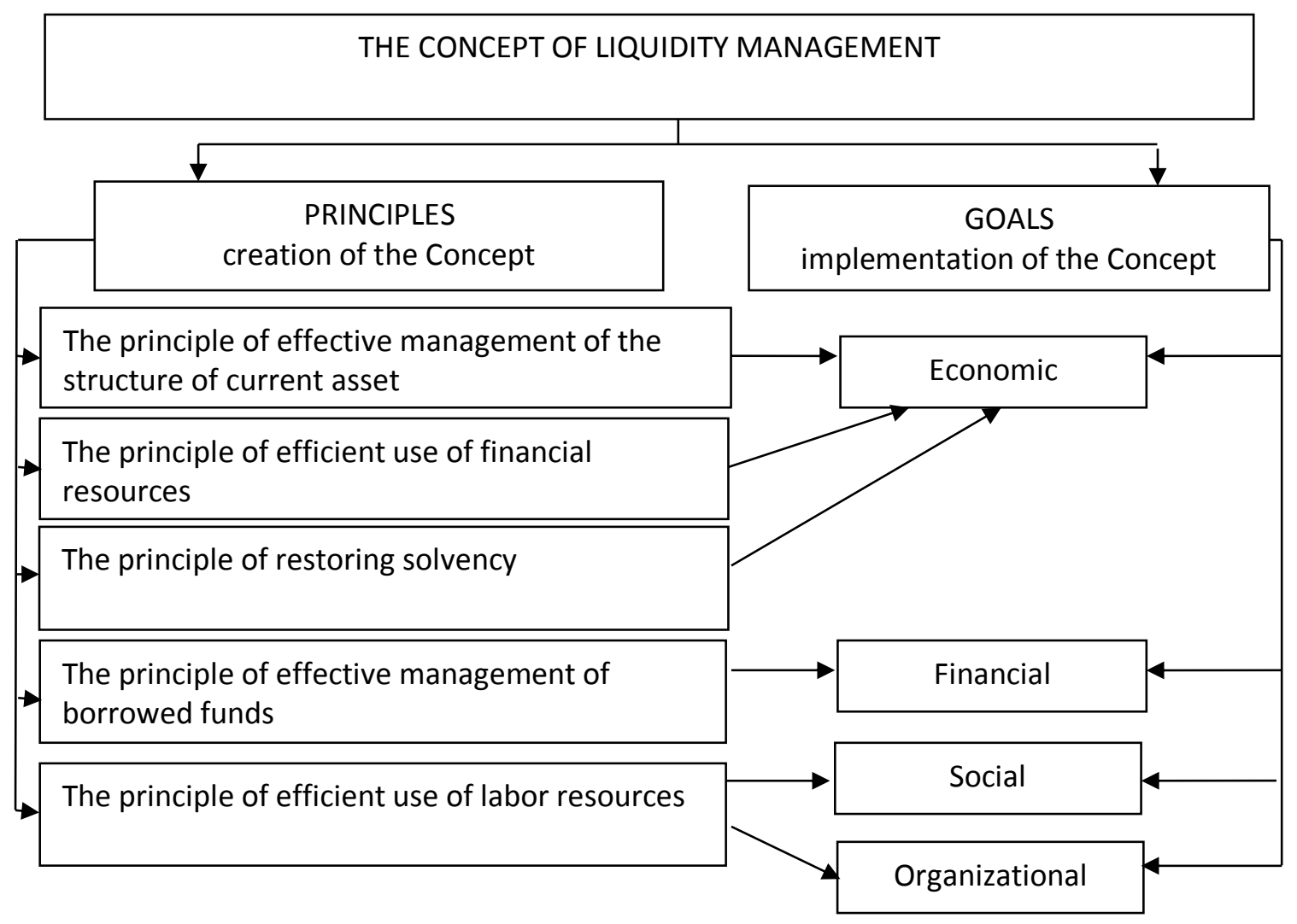

The main principles of the Concept of liquidity management of engineering companies are as follows:

1) the principle of effective management of the structure of circulating assets, which implies the formation of an optimal, in terms of liquidity, share of each element of circulating assets, which does not lead to inhibition of their turnover. The effectiveness of the implementation of this principle will determine the verification of the company's balance sheet for liquidity, the calculation of liquidity ratios and the turnover of current assets by elements;

2) the principle of efficient use of financial resources, which presupposes the achievement of the standard level of liquidity and efficiency of cash flows. The effectiveness of the implementation of this principle will reveal the analysis of the dynamics and structure of cash flows by types of operations (current, investment and financial), as well as an assessment of the liquidity and efficiency of cash flows;

3) the principle of restoring solvency, which assumes, in a short time, the company's ability to increase the level of its solvency if the standard values of liquidity ratios are not achieved, a low level of liquidity of cash flows from current operations, but with an emerging trend of growth of these indicators in the dynamics of a number of analyzed periods;

4) the principle of effective management of borrowed funds, which involves reducing the debt burden, drawing up a flexible schedule for repayment of obligations, managing accounts payable;

5) the principle of efficient use of labor resources, which involves high labor productivity and timely payment of wages, incentives, bonuses for high results of labor activity. 
The interaction of goals and principles of the proposed universal author's Concept of liquidity management for a machine-building company is presented in Figure 1.

The implementation of the Concept will be carried out in the following areas:

a) organizational support (improving the organizational structure, changing the company's personnel policy, appointing responsible persons for each stage of analysis and assessment of the risk of insolvency);

b) efficient use of reserves (including their competent rationing);

c) increasing the turnover of accounts receivable, work with debtors, development of payment terms for manufactured products, sale of accounts receivable on a factoring basis.

Based on the results of the analysis of solvency, in identifying problem areas, the main measures were identified for restructuring the balance sheet of the machine-building company JSC "Kopeysk Machine-Building Plant" and increasing its liquidity:

a) reduction of stocks in terms of finished products in the warehouse;

b) the sale of receivables on the basis of factoring and an increase in the turnover of receivables on this basis.

The economic substantiation of the developed measures to increase liquidity and the diagnostics carried out showed that the following dynamics of financial results is characteristic of this group of machine-building companies.

So, in general, according to all data of the engineering company 2017-2018. there is a decrease in income and expenses from core activities:

a) sales revenue decreased by $25.86 \%$ or 785,424 thousand rubles;

b) the cost price decreased by $20.27 \%$ or 445,255 thousand rubles;

c) gross profit decreased by $40.47 \%$ or 340,169 thousand rubles;

d) selling expenses decreased by $28.73 \%$ or 9853 thousand rubles;

e) administrative expenses decreased by $8.04 \%$ or 45,936 thousand rubles;

f) profit from sales in 2017 decreased to a loss in 2018 by 284,380 thousand rubles.

For the period 2018-2019 the situation is changing for the better. Income and expenses from core activities increased, which led to a positive financial result of core activities - sales profit.

\section{Discussion}

In modern economic conditions, the risk of insolvency is quite high and financial discipline suffers. According to the authors Babintseva (2014); Baranova (2017); Gubarenko (2016), when analyzing the financial and economic situation, great importance is attached to the analysis of solvency, assessment of liquidity, assessment of the risks of insolvency and the likelihood of bankruptcy. In this regard, the development of a digital analysis model and assessment of the risk of insolvency is increasing. But at the same time, the main form of reporting, in which the payment history of the company is most informatively presented, is the cash flow statement. It is with the help of this reporting form that it is possible to track in which areas of activity the enterprise made settlements and payments, what cash inflows were generated, in what volume all obligations were paid off, what cash balances the company has at its disposal after the completed calculations, what was the level liquidity and 
efficiency of its cash flows. Therefore, the analysis of cash flows will directly show what risks of insolvency may be in a modern economy.

In recent years, the issues of assessing solvency have become increasingly common in the economic literature of the authors Karzayev (2017), Kolesnik y Stanchulyak (2017), Konstantinova (2017), and are also the subject of discussions and discussions in various forums. Our author's position is to develop a digital model for analyzing and assessing the risk of insolvency, which will comprehensively analyze the solvency and liquidity, liquidity and efficiency of its cash flows.

- To achieve this goal, it is planned to solve a number of interrelated tasks:

- to evaluate the different approaches of different authors to the basics of analysis and assessment of the risk of insolvency;

- substantiate the development of a digital model of analysis and risk and determine the algorithm for its application;

- to develop a methodology for analyzing and assessing the risk of insolvency for joint-stock machinebuilding companies in Russia;

- to develop a concept for a digital liquidity management model to reduce the risk of insolvency.

\section{Conclusion}

Based on the results of the study, conclusions can be drawn about the achievement of its goals and objectives, namely:

the approaches of different authors to the basics of analysis and assessment of the risk of insolvency are revealed. Thus, insolvency is a failure to fulfill the obligations presented above. The reasons for the risk of insolvency or financial insolvency can be divided into three groups:

a) lack of desire to fulfill current obligations;

b) lack of cash or liquid assets with which these liabilities can be repaid;

c) improper use of working capital (formation of large amounts of accounts receivable, which increases the risks of its transition into overdue debt, overestimation of the usual need for reserves and the formation of stocks of stale raw materials in the warehouse, etc.)

The authors of this study concluded that it is advisable to supplement the assessment of solvency with an analysis of cash flows, which will provide a real picture of the amount of funds received and spent, identify the risks of insufficient funds by a certain date and develop a schedule of receipts and payments in order to manage cash flows;

substantiated the need to develop a digital model of analysis and assessment of the risk of insolvency of the enterprise, an algorithm for its application. The proposed digital model includes the following areas of analysis and assessment:

a) assessment of balance sheet liquidity and calculation of liquidity ratios;

b) assessment of the turnover of current assets;

c) assessment of liquidity and efficiency of cash flows;

d) assessment of loss (restoration) of solvency;

e) SWOT-analysis, which identifies the risks of reducing the liquidity of the enterprise; 
the improved methodology of analysis and assessment of the risk of insolvency of the enterprise was tested on the example of JSC "Kopeysk Machine-Building Plant".

\section{References}

Babintseva, N.V. (2014) Methodology of a comprehensive comparative rating assessment of solvency and financial stability of an enterprise [Metodología de una evaluación integral de calificación comparativa de solvencia y estabilidad financiera de una empresa]. Economics and Entrepreneurship. Economía y emprendimiento. - No. 11-4 (52-4). - pp. 609-612 (In Russian).

Baranov A.N. (2017) Management of liquidity and solvency of the enterprise [Gestión de liquidez y solvencia de la empresa]. Economics and society. Economía y sociedad. - No. 6-1 (37). - pp. 228-231 (In Russian).

Volosevich N.V. (2015) Balance of cash flows as a necessary condition for ensuring the solvency of organizations [Balance de flujos de efectivo como condición necesaria para garantizar la solvencia de las organizaciones]. Economics and Entrepreneurship. Economía y emprendimiento. - No. 5-1 (58-1). - pp. 1003-1006 (In Russian).

Gradov, A.P. (2014) Strategy and tactics of crisis management of the company [Estrategia y tácticas de gestión de crisis de la empresa]. - St. Petersburg: Special Literature. Literatura especial.- 510 p.

Gubarenko, A.O. (2016) Integral assessment of solvency of enterprises [Evaluación integral de la solvencia de las empresas]. Proceedings of the international scientific and practical forum. Actas del foro internacional científico y práctico.- pp. 470-473.

Dontsova, L.V., Nikiforova, N.A. (2015) Analysis of financial statements [Análisis de estados financieros]: textbook. - M .: Business and Service. Negocios y servicio.- $368 \mathrm{p}$.

Duysembieva A.E., Asemova R.D. (2016) Methodological approaches in assessing the solvency of commercial organizations [Enfoques metodológicos para evaluar la solvencia de las organizaciones comerciales]. Science and Peace. Ciencia y paz. - No. 6 (34). - pp. 34-35.

Zotova E.V., Butler T.V. (2017) Assessment of financial risks of the enterprise [Evaluación de riesgos financieros de la empresa]. Studium. Studium - No. 2 (43). -p. 5.

Ilyina N.O., Ukolova S.I. (2017) Analysis of the liquidity of the enterprise as an element of organization management [Análisis de la liquidez de la empresa como elemento de gestión organizacional]. Politics, Economics and Innovations. Política, economía e innovaciones. - No. 2 (12). - p. 10.

Karzayev, E.A., Karzayev, V.A. (2017) Assessment of the solvency of the enterprise on the basis of future cash flows [Evaluación de la solvencia de la empresa sobre la base de los flujos de efectivo futuros]. Financial Management. Gestión financiera. - No. 1. - pp. 17-26.

Kovalenko, O.G. (2016) Assessment of the solvency of the enterprise on the basis of future cash flows [Problemas reales de gestión de solvencia en condiciones modernas]. Karelian scientific journal. Revista científica de Carelia.- T. 5. - No. 4 (17). - pp. 142-144.

Kovalenko O.G., Kurilova A.A. (2016) Methodology for assessing the solvency of the enterprise [Metodología para evaluar la solvencia de la empresa]. Karelian Scientific Journal. Karelian Scientific Journal. - T. 5. - No. 4 (17). - pp. 135-138.

Kovalenko, O.G. (2016) Methodology for assessing the solvency of the enterprise [Solvency of the enterprise]. Vestnik NGIIE. Vestnik NGIIE. - - No. 12 (67). - pp. 153-157.

Kolesnik N.F., Stanchulyak Yu.N. (2017) Features of the formation of estimated reserves and their impact on the solvency indicators of the enterprise [Características de la formación de reservas estimadas y su 
impacto en los indicadores de solvencia de la empresa]. Financial analytics: problems and solutions. Analítica financiera: problemas y soluciones.- No. 2 (332). - pp. 192-204.

Konstantinov K.K. (2017) Assessment of the solvency of the enterprise on the basis of liquidity analysis [Evaluación de la solvencia de la empresa sobre la base del análisis de liquidez]. Actual problems of the humanities and natural sciences. Problemas reales de las humanidades y las ciencias naturales. - No. 5-4. pp. 60-63.

Kudryavtsev, D.S. (2015) Methods of analysis and assessment of the risk of insolvency of small businesses: a dissertation for the degree of candidate of economic sciences [Métodos de análisis y evaluación del riesgo de insolvencia de las pequeñas empresas: una disertación para el grado de candidato de ciencias económicas]. M.: Financial University under the Government of the Russian Federation. Universidad financiera bajo el gobierno de la Federación de Rusia.- 172 p.

Kurmaleeva, R.R., Grudina, S.I. (2017) Evaluation and analysis of liquidity and solvency indicators in the conditions of economic instability [Evaluación y análisis de indicadores de liquidez y solvencia en condiciones de inestabilidad económica]. Scientific Review. Revisión científica. - No. 17. - pp. 58-61.

Lyagoshina, E.M. (2017) Methodology for assessing the solvency and liquidity of the enterprise [Metodología para evaluar la solvencia y liquidez de la empresa]. Collection of articles of a scientific and practical seminar. Colección de artículos de un seminario científico y práctico.- pp. 55-58.

Nagapetyan, A.S., Kulay, S.V. (2017) Analysis of solvency of the enterprise [Análisis de solvencia de la empresa]. Economics and society. Economía y sociedad. - No. 2 (33). - pp. 732-736.

Savitskaya, G.V. (2015) A comprehensive analysis of the economic activity of the enterprise [Un análisis exhaustivo de la actividad económica de la empresa]: textbook. - M .: INFRA-M. - 607 p.

Smirnov, P.A., Trofimova, M.N. (2015) Analysis of solvency of the enterprise [Análisis de solvencia de la empresa]. European research. Investigación europea. - No. 4 (5). - pp. 15-16.

Tronin, S.A. (2017) The main methods for assessing the financial stability and solvency of the enterprise [Los principales métodos para evaluar la estabilidad financiera y la solvencia de la empresa]. Forum. Series: Humanities and Economics. Humanidades y economía. - No. 2 (11). - pp. 84-89.

Fashchevsky, V. N. (2017) About the solvency of enterprises [Sobre la solvencia de las empresas]. Finance. Finanzas. - No. 3. - p. 33.

Fomchenkova, S.V. (2015) Altman model as a way of assessing the solvency of an enterprise [El modelo Altman como una forma de evaluar la solvencia de una empresa]. Bulletin of science and education. Boletín de ciencia y educación. - No. 4 (6). - pp. 134-137.

Khadieva, L.M. (2017) On the issue of assessing financial stability and solvency of an enterprise [Sobre el tema de evaluar la estabilidad financiera y la solvencia de una empresa]. Collection of articles of the international scientific-practical conference. Colección de artículos de la conferencia internacional científico-práctica. - pp. 190-192.

Chernikova, A.I., Vishnyakova, A.B. (2016) Assessment of solvency based on liquidity indicators of industrial enterprises [Evaluación de solvencia basada en indicadores de liquidez de empresas industriales]. Science of the XXI century: current trends of development. Ciencia del siglo XXI: tendencias actuales de desarrollo. No. 2-2. - pp. 25-32

Esta obra está bajo una Licencia Creative Commons Attribución-NoCommercial 4.0 International

(cc) BY-NC 